\title{
Working
}

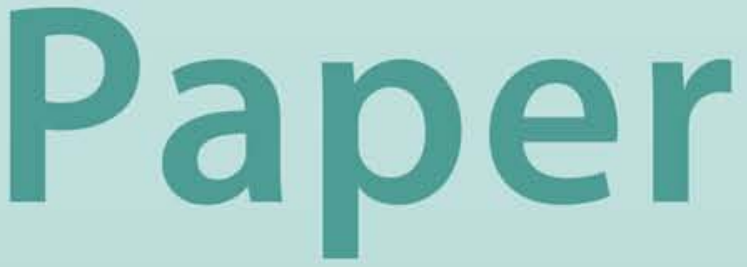




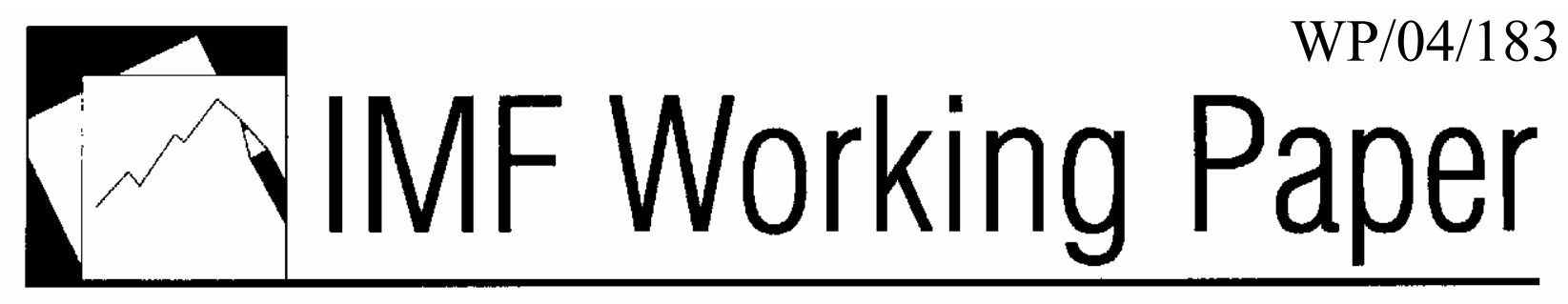

\section{Intercreditor Distribution in Sovereign Debt Restructuring}

Ousmène Jacques Mandeng 


\title{
IMF Working Paper
}

Western Hemisphere Department

\section{Intercreditor Distribution in Sovereign Debt Restructuring}

\author{
Prepared by Ousmène Jacques Mandeng ${ }^{1}$ \\ Authorized for distribution by Guy Meredith
}

September 2004

\begin{abstract}
This Working Paper should not be reported as representing the views of the IMF. The views expressed in this Working Paper are those of the author(s) and do not necessarily represent those of the IMF or IMF policy. Working Papers describe research in progress by the author(s) and are published to elicit comments and to further debate.

Intercreditor equity represents one of the main objectives of bankruptcy proceedings. Yet, recent restructurings of sovereign debt suggest that violation of intercreditor equity is common. While existing contractual provisions, and guidelines issued by creditor committees, establish fundamental principles about creditor treatment, they seem to remain too vague to guide debt restructuring processes effectively. The paper focuses on distribution, and argues that lack of clear guidelines for distribution may complicate and delay the resolution process and induce undue uncertainty about the predictability and viability of the restructuring outcome. The paper discusses and proposes parameters which may contribute to establishing explicit principles for the assessment of intercreditor equity in distribution.
\end{abstract}

JEL Classification Numbers: F34, G15, H63

Keywords: Aggregation problem, collective action, intercreditor equity, Paris Club Author(s) E-Mail Address: omandeng@,imf.org

\footnotetext{
1 The paper greatly benefited from comments from Markus Krgier, Carl Lindgren, Steven Phillips, Robert Rennhack, Arnim Schwidrowski, and Roberto Steiner.
} 


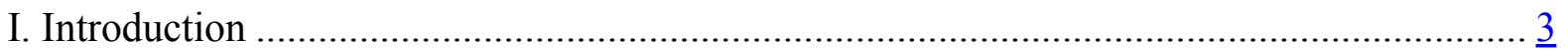

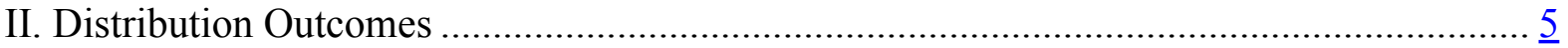

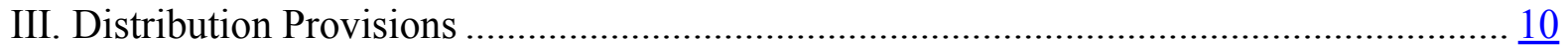

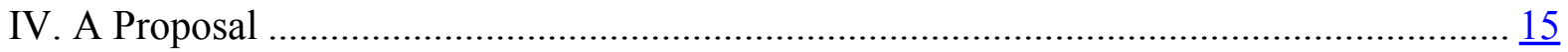

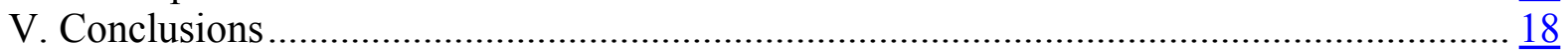

A. Restructuring Parameters ............................................................................. $\frac{19}{21}$

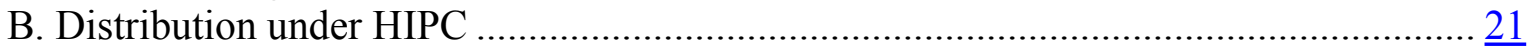

C. Present Value Accounting Principles ................................................................ 23

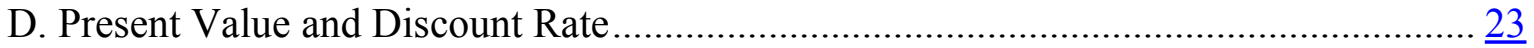

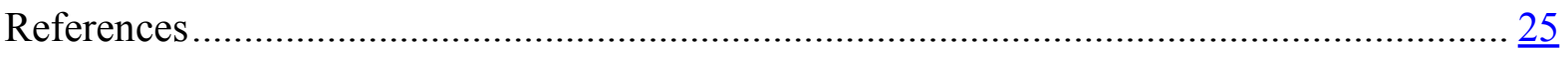

Figures

1. Present Value and Discount Rates .................................................................... 24

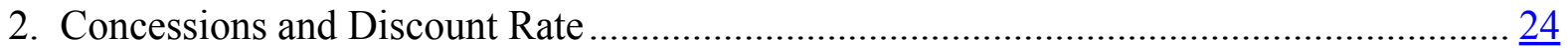

\section{Tables}

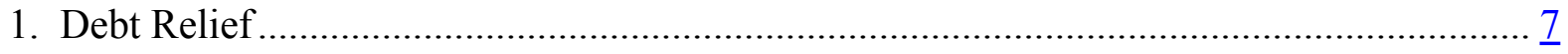

2. Pre- and Post-Restructuring Present Value, Cash-flow, Average Life ............................ 9

3. Ecuador Exchange of August 2000 ............................................................................

4. Paris Club Restructuring Terms.............................................................................. $\frac{19}{20}$

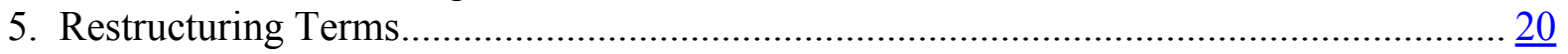

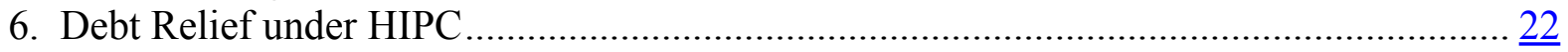




\section{INTRODUCTION}

Intercreditor equity in distribution represents one of the main objectives of bankruptcy proceedings. Yet, recent restructurings of sovereign debt suggest that violation of equitable distribution is common. While existing contractual provisions and guidelines issued by creditor committees establish fundamental principles about creditor treatment, they seem to remain too vague to guide debt restructuring processes effectively. Lack of clear guidelines in debt restructuring may complicate and delay the resolution process, cause creditor discontent heightening risk of holdouts, and induce unnecessary uncertainty about the predictability and viability of the restructuring outcome. Such uncertainties, in turn, can unduly increase the cost of debt restructurings (EMTA, 2001; IMF, 2001; Rogoff and Zettelmeyer, 2002). ${ }^{2}$

The current debate about sovereign debt restructuring highlights the need for clearer guidelines. Deutsche Bank CEO Josef Ackermann echoed the lack of common rules in a recent article on emerging markets finance stating that there is a "broad need for an agreed guide to the restructuring of sovereign debt [...] but there has been no agreement so far on guidance for all parties involved." 3 The controversy over intercreditor treatment became apparent recently with regard to the Dominican Republic, where investment banks' reports in light of the country's payment obligations to bondholders in early 2004 and its credit downgrade in January 2004 revealed substantial uncertainty as to the implication of debt restructuring for different creditor groups. ${ }^{4}$ The Argentine government in December 2003 filed a request with a New York court asking to clarify the principle of pari passu in Argentine loan contracts, highlighting that even standard covenants in loan contracts relevant for debt restructuring remain ambiguous.

\footnotetext{
${ }^{2}$ Former first deputy managing director of the IMF Stanley Fischer in an address in October 1998 made the following statement about the need to reform the role of the private sector in sovereign debt workouts: "There is great concern about the difficulties the international system has in lending to countries without bailing out private sector participants. We need a system, and we are developing it, for making sure that an appropriate contribution is made by the private sector to the resolution of crises [...]"

${ }^{3}$ Financial Times U.S. edition, Comment, p. 15, February 17, 2004.

${ }^{4}$ The credit rating agency, Moody's, downgraded the Dominican Republic from B3 to Caa1 citing that "it is not clear how negotiations with official bilateral creditors will affect bondholders in the context of "comparability of treatment", Moody's press release, rating action, January 30, 2004.
}

The Swiss investment bank UBS, in a research report of February 27, 2004 (Emerging Markets Daily Comments), wrote "[r]responding to rumors that the PDI payment due February 27 would not be paid until agreement was reached with the Paris Club a senior Central Bank official told us that the authorities are following a clear strategy, under their IMF program, of working with financial/legal advisors in dealing with their request for a Paris Club rescheduling. [...] we believe, [that] a default — even if demanded by the Paris Club - would complicate the Dominican government's relations with the IMF." 
The notion of intercreditor equity in debt restructuring refers mostly to representation and distribution. The former determines creditor participation and voting for amending or changing loan terms, particularly in the event of debtor distress, emphasizing the need for creditor coordination and dispute mechanisms. The latter establishes the claim each creditor receives after restructuring in exchange of the original claim. The recent debate about appropriate sovereign debt restructuring has centered on creditor representation with regard to the Sovereign Debt Restructuring Mechanism (SDRM) and collective action clauses (Dixon and Wall, 2000; Eichengreen, 2003; Ghosal and Miller, 2003; IMF, 2002; Krueger, 2002; Rogoff and Zettelmeyer, 2002). ${ }^{56}$ However, little attention has been paid to principles guiding distribution (IMF, 2003). ${ }^{7}$ While distribution in individual debt issues is being addressed in loan contracts, the presence of different debt issues makes inter-debt issue and intercreditor group distribution considerably more complex. Lack of clear principles for distribution may undermine creditor confidence that equitable distribution is achievable and, as such, that fundamental principles of intercreditor equity are observed. ${ }^{8}$

The present paper discusses parameters that may contribute to establishing basic guidelines for the assessment of intercreditor equity in distribution in sovereign debt restructuring based on the notion of pro-rata distribution in debt and cash flow reductions and average life extension. As such, the paper aims at contributing to the empirical and policy literature to address collective action and aggregation problems with regard to principles of distribution

\footnotetext{
5 The relevance of intercreditor equity can also be seen in the economic literature with regard to the concepts of fairness and envy. An allocation is said to be equitable if no agent prefers the allocation of any other agent (Pazner and Schmeidler, 1978). Equity does not need to imply the comparison of one agent's valuation of his allocation with another agent's valuation of her allocation and affect economic behavior. The economic literature assumes that if agents are indifferent between receiving a fractional allocation and the allocation that he or she actually received, an allocation is still equitable (Brams and Taylor, 1996; Thomson and Varian, 1985). Fairness and envy have been found in empirical studies to have a significant impact on economic behavior: i) "people are willing to sacrifice their own material well-being to help those who are being kind contingent upon perceiving the other as doing his fair share; ii) people will in some situations not only refuse to help others, but will sacrifice to hurt others who are being unfair; and iii) people will not be as willing to sacrifice a great amount of money to maintain fairness as they would be with small amounts of money" (Rabin, 1993).
}

The notion of fairness and the relationship between fairness and economic behavior suggest that rules to guide intercreditor equity should provide for an outcome that participants themselves consider as satisfactory and where the outcome can be implemented without having to rely on arbitration by an outside party. Equity rules may strengthen the bargaining process among creditors by providing transparent and verifiable guidelines for the debt restructuring process. Satisfaction with the restructuring outcome lies in the perception of equitable participation by creditors which should help to maximize concessions and minimize creditor dissent.

${ }^{6}$ Proposals for a sovereign debt restructuring mechanisms, a factsheet, January 2003; available via the Internet at www.imf.org/external/np/exr/facts/sdrm.htm.

${ }^{7}$ A recent IMF (2003) study concluded that "[d]ifficu sessin g and achieving intercreditor equity both among private creditors and between private and official creditors can complicate and delay the process of achieving broad participation in an agreement."

${ }^{8}$ The SDRM addressed explicitly problems of intercreditor group and inter-debt issue equity but did not develop principles for distribution. 
and valuation as basic elements toward developing a code of conduct in sovereign debt restructuring (Couillault and Weber, 2003; Eichengreen, 2003; Eichengreen and Mody, 2003; IMF, 2002, IMF, 2003). ${ }^{9}{ }^{10}$ While the notion of code of conduct seems to be associated more with the contractual approach in sovereign debt restructuring, standards of distribution are deemed to be equally relevant in a statutory framework.

The paper abstracts from creditor priority, representation and voting, and free-rider problems. Instead it addresses the relationship of equally ranked and generally unsecured creditors within a class and across classes for distribution purposes focusing on bilateral official and commercial creditors. The paper is also not concerned with the question whether debt restructuring is desirable in the first place nor with the appropriateness of a given debt relief (Friedman, 2000); nor are possible implications of debt relief for future financing by individual creditor groups discussed.

The paper reviews selected distribution outcomes in recent sovereign debt restructurings and existing parameters of distribution and valuation that determine intercreditor equity in debt restructurings. The second part discusses actual outcomes of recent sovereign debt restructurings and illustrates deviations from intercreditor equity in distribution from a distribution of concessions by creditors proportional to their pre-restructuring exposure. The third part reviews distribution provisions in legislation, in standard loan and bond contracts under English and New York laws, and in guidelines issued by creditor committees. The fourth part presents a proposal that may provide more effective guidelines for distribution to allow a more transparent assessment of whether equitable distribution is being achieved. The last part offers some conclusions.

\section{Distribution OUTCOMES}

Recent sovereign debt restructuring agreements show a broad range of distribution outcomes and reveal nonuniform treatments of private and official creditors. The differences between official and private creditors but also among private creditors seem to suggest violation of equitable distribution. The restructurings reviewed are the 1999/2000 Ecuador and the 1998/1999 Russia agreements that are among the most controversial recent sovereign debt restructurings. ${ }^{11}$

\footnotetext{
9 The aggregation problem addresses the difficulty of coordinating creditors holding distinct bond issues (Eichengreen and Mody, 2003).

${ }^{10}$ The central bank of France put forward a "code of good conduct" to lay general principles to be adhered to by creditors and debtors (Couillault and Weber, 2003). The code refers to distribution indicating that "proceeds should be distributed pro rata" and that "procedures should ensure comparable treatment among creditors" but does not develop needed valuation principles to provide a practical guide towards the assessment of distribution and comparable treatment.

11 The Emerging Markets Traders Association (EMTA) attested that "[m]any investors already concerned about the general nature of comparable treatment will argue that private creditors in Russia and Ecuador will, in effect, have 'bailed out' the official sector" (EMTA, "Burden-Sharing in 2001: Now it's time to reform the Paris Club," February 13, 2001, www.emta.org/emarkets/burden5.pdf).
} 
Equitable distribution is based on the comparison of pre- and post-restructuring loan terms and considered to be achieved here when different creditor groups make similar proportional concessions in terms of cash-flow relief, extension of average life, and reduction in present value of the claims. The paper acknowledges that a direct comparison of official bilateral and commercial creditors is complicated because of the numerous different provisions underlying the restructuring agreements (Appendix A). Data limitations imply that the extent of concessions granted by different creditor groups with regard to their total exposure may be overstated.

The assessment is based on all original cash flows for commercial bonds and Paris Club obligations being laid out as scheduled prior to the actual exchange date and discounted at 11.25 percent for Ecuador and 9 percent for Russia (Table 1). ${ }^{12}{ }^{13}$ The discount rates reflect the yields at which Ecuador and Russia issued their debt to commercial creditors in tranquil times. ${ }^{14}$ The calculations of present value are based on discounting all pre- and postrestructuring cash flows by the same discount rate to allow comparison of pre- and post-restructuring exposures. The present value of future receipts is computed under the economic accrual method, using the same compounding interval and financial conventions to compute the yield on these receipts and is equal to the present value of all unconditionally payable receipts to be received from and payments to be paid for an asset after a given date, using the yield on the asset as the discount rate. ${ }^{15}$

\footnotetext{
${ }^{12}$ Given the limited public information about Paris Club obligations, several approximations were made to establish pre- and post-restructuring cash flows.

${ }^{13}$ The Russian commercial debt restructuring assumes equitable treatment between Eurobonds, MinFins, and Prins and IANs as all correspond to unsecured obligations. This does not imply that MinFins or Prins and IANs should not trade at a discount to Eurobonds.

${ }^{14}$ The yields are therefore significantly lower than implied secondary market yields prior to the restructuring agreement.

${ }^{15}$ Data on commercial debt are limited to publicly placed foreign exchange bonds and taken from Bloomberg. As such commercial debt only represents a subset of the actual exposure of commercial creditors and the level of concessions extended is therefore probably overstated. The restructuring terms are taken from the prevailing offering prospectuses distributed at the time of restructuring.
}

The official debt data and restructuring terms come from the Paris Club website (www.clubdeparis.org). However, as the Paris Club publishes very aggregate data limited to rescheduled flows the calculations are accordingly only gross approximations of actual payment terms. The Paris Club normally only treats so-called pre-cutoff date debt and the data are therefore only a subset of the total exposure of official bilateral creditors. Firm conclusions about changes in the overall exposure of official bilateral creditors cannot therefore be made with the data probably overestimating actual concessions extended by the Paris Club. 
Table 1: Debt Relief

\begin{tabular}{|c|c|c|c|}
\hline & $\begin{array}{r}\text { Pre- } \\
\text { restructuring } \\
\text { present value } \\
\text { (US\$ million) }\end{array}$ & $\begin{array}{r}\text { Post- } \\
\text { restructuring } \\
\text { present value } \\
\text { (US\$ million) }\end{array}$ & $\begin{array}{r}\text { Present value } \\
\text { reduction } \\
\text { (percent) }\end{array}$ \\
\hline Ecuador $\dagger$ & 6,731 & 5,919 & -12.1 \\
\hline Paris Club * & 2,095 & 1,831 & -12.6 \\
\hline Commercial creditors & 4,636 & 4,087 & -11.8 \\
\hline $\operatorname{Par}^{1 /} 873$ & & 926 & 6.0 \\
\hline Discount ${ }^{1} / 1,156$ & & 1,049 & -9.3 \\
\hline $\mathrm{PDI}^{2} / 1,872$ & & 1,600 & -14.5 \\
\hline $\mathrm{IE}^{3} / 172$ & & 111 & -35.7 \\
\hline $11 \frac{1 / 4}{02^{3 /}} 394$ & & 282 & -28.5 \\
\hline FRN $04^{3} / 169$ & & 120 & -28.9 \\
\hline Russia $\ddagger$ & 86,897 & 75,296 & -13.4 \\
\hline Paris Club $* *$ & 44,090 & 42,811 & -2.9 \\
\hline Commercial creditors & 42,807 & 32,485 & -24.1 \\
\hline Prins $^{4 /} 19,01$ & 5 & 10,441 & -45.1 \\
\hline $\mathrm{IANs}^{4 /} 4,416$ & & 3,204 & -27.4 \\
\hline MinFin III ${ }^{5 /} 1,518$ & & 981 & -35.4 \\
\hline MinFin IV I/ $_{2,755}$ & & 2,755 & 0.0 \\
\hline MinFin $\mathrm{V}^{6 /} 1,820$ & & 1,820 & 0.0 \\
\hline MinFin VI ${ }^{6 /} 1,217$ & & 1,217 & 0.0 \\
\hline MinFin VII ${ }^{6 /} 1,009$ & & 1,009 & 0.0 \\
\hline $9^{1 / 4} 2001^{6 / 9} 987$ & & 987 & 0.0 \\
\hline ITL $92003^{6 / 7} 768$ & & 768 & 0.0 \\
\hline $113 / 42003^{6 /} 1,417$ & & 1,417 & 0.0 \\
\hline DEM $92004^{6 /} 1,032$ & & 1,032 & 0.0 \\
\hline DEM $9^{3 / 8} 2003^{6 / 6} 655$ & & 655 & 0.0 \\
\hline $102007^{6 / 3} 3,028$ & & 3,028 & 0.0 \\
\hline $123 / 42028^{6 /} 3,172$ & & 3,172 & 0.0 \\
\hline
\end{tabular}

Source: Bloomberg; Paris Club; and author's calculation. Restructuring terms of commercial debt are based on the offering prospectuses.

$\dagger$ All cash flows discounted at 11.25 percent. Swap rate of 7 percent for Discount, PDI, IE, and FRN 04.

+ All cash flows discounted at 9.00 percent. Swap rate of 6 percent for Prins and IANs. Excludes bonds issued in exchange of domestic treasury bills (GKOs) and unsecured export credits (FTOs). Prins and IANs are not pari passu with Eurobonds. MinFin Bonds (restructured foreign currency bank deposit liabilities) are issued domestically and not pari passu with Eurobonds.

* September 2000. Total stock outstanding, of which US\$830 million treated debt.

** August 1999. Total stock outstanding, of which US\$8,047 million treated debt.

$1 /$ Exchanged for cash and 2030 Bonds.

2/ Exchanged for cash, 2012, and 2030 Bonds.

3 / Exchanged for cash and 2012 Bonds.

4/ Exchanged for 2010 and 2030 Bonds. 2010 Bonds paid 9.5 percent of face value upon exchange.

5/ Exchanged for MinFin VIII due 2007.

6/ Not restructured. 
The Ecuador and Russia restructurings reveal significant discrepancies in debt reductions in present value terms. The Ecuador restructuring shows a homogenous treatment of official bilateral and commercial debt but reveals substantial intra-commercial creditor differences. While holders of Par bonds received an increase in present value, due to the significant amount of cash received, holders of IE bonds suffered a decline in present value of 36 percent. The Russia restructuring indicates a significant difference in the treatment of official bilateral and commercial debt in present value terms. The exclusion of Eurobonds in the restructuring and important differences in present value reduction between Prins, IAN, and MinFin III bonds reveal even larger differences in the treatment of commercial creditors.

The restructuring terms based on cash flow and average life reveal further discrepancies in relative concessions extended by commercial and official creditors (Table 2). Cash flow is calculated as total debt service over a set time span taken here as the period of an IMF arrangement that is in place during the restructuring period. Average life is calculated as the average time a loan or bond with a sinking funds remains outstanding. ${ }^{16}$ The data reveal that the Ecuador restructuring shows marked discrepancies in terms of cash-flow relief and average life of debt outstanding. The high proportion of cash paid in the Ecuador exchange implies an increase in cash flow during 2000-01, while the average life of commercial debt has remained significantly longer than that of official bilateral creditors. The Russia exchange shows a significant greater proportional cash-flow relief by commercial creditors compared with official creditors, with the average life of commercial debt being extended but only to reach the length of official bilateral creditors.

The Ecuador exchange illustrates the non-linear effect of different discount factors on the present value of different instruments (Table 3). Differences between the actual exchange and a hypothetical exchange at a given yield therefore indicate that the level of the discount rate (yield) may determine significantly the distribution outcome of participating creditors.

\footnotetext{
${ }^{16}$ A loan with a bullet maturity has an average life equal to the remaining time to maturity; a loan with a sinking fund has an average life shorter than its final maturity, e.g., the Paris Club graduated repayment structure (progressive payments over the life of the debt) implies that the average life of the debt is significantly shorter than its final maturity.
} 
Table 2. Pre- and Post-Restructuring Present Value, Cash Flow, Average Life

\begin{tabular}{|c|c|c|c|c|c|c|}
\hline & $\begin{array}{c}\text { Pr } \\
\text { restructuring } \\
\text { present value } \\
\text { (US\$ million) }\end{array}$ & $\begin{array}{r}\text { Post- } \\
\text { restructuring } \\
\text { present value } \\
\text { (US\$ million) }\end{array}$ & $\begin{array}{r}\text { Pre- } \\
\text { restructuring } \\
\text { cash flow } \\
\text { (US\$ mil- } \\
\text { lion) } \dagger\end{array}$ & $\begin{array}{r}\text { Post- } \\
\text { restructuring } \\
\text { cash flow } \\
\text { (US\$ mil- } \\
\text { lion) } \dagger\end{array}$ & $\begin{array}{r}\text { Pre- } \\
\text { restruc- } \\
\text { turing } \\
\text { average } \\
\text { life } \\
\text { (years) } \ddagger\end{array}$ & $\begin{array}{r}\text { Post- } \\
\text { restruc- } \\
\text { turing } \\
\text { average } \\
\text { life } \\
\text { (years) } \$\end{array}$ \\
\hline Ecuador $*$ & 6,731 & \multicolumn{2}{|c|}{$5,9192,0121,618$} & \multirow{3}{*}{389} & \multirow{3}{*}{$\begin{array}{r}12.5 \\
5.0\end{array}$} & \multirow{3}{*}{$\begin{array}{r}15.8 \\
8.1\end{array}$} \\
\hline Paris Club & 2,095 & 1,831 & 1,178 & & & \\
\hline of which arrears & 816 & \multicolumn{2}{|r|}{816} & & & \\
\hline Commercial creditors & 4,636 & 4,087 & 834 & \multirow[t]{2}{*}{1,229} & \multirow[t]{2}{*}{16.0} & \multirow[t]{2}{*}{19.2} \\
\hline of which arrears & 334 & \multicolumn{2}{|r|}{334} & & & \\
\hline Russia ** & 86,897 & 75,296 & 13,358 & \multirow[t]{5}{*}{8,365} & 8.6 & 9.9 \\
\hline Paris Club & 44,090 & 42,811 & $, 1935,341$ & & 9.1 & 9.9 \\
\hline of which arrears & 3,546 & & 3,546 & & & \\
\hline Commercial creditors & 42,807 & 32,485 & $, 1653,024$ & & 7.9 & 9.9 \\
\hline of which arrears & 2,910 & & 2,910 & & & \\
\hline
\end{tabular}

Source: Bloomberg; Paris Club; and author's calculation. Data as per Table 1.

$\dagger$ in present value terms including arrears and cash payments where applicable.

† time weighted cash flow of principal payments including arrears and cash payments where applicable.

* discounted at 11.25 percent. Cash flow for 2000-01 as IMF Stand-By Arrangement covered April 2000 through December 2001.

Commercial creditors received cash payment of US\$968 million upon exchange. Released collateral of US\$350 million was used toward cash payments.

** discounted at 9.00 percent. Cash flow for 1999-00 as IMF Stand-By Arrangement covered July 1998 through December 2000. Commercial creditors received additional bonds for accumulated arrears and a cash payment of 9.5 percent of outstanding arrears on Prins and IANs.

Assumed restructuring for commercial debt is March 2000.

Table 3. Ecuador Exchange of August 2000

\begin{tabular}{lrrrrrr}
\hline \multicolumn{5}{c}{ Present Value Reduction at Selected Discount Factors (percent)* } & \\
Discount rate & Par & Discount & \multicolumn{1}{c}{ PDI } & IE $\quad 11.2502$ & FRN 04 \\
\hline 10.00 & 33.95 & 37.45 & 9.5450 .0614 .9619 .88 & \\
11.25 & 32.75 & 37.54 & 12.0155 .3821 .1324 .20 & \\
12.00 & 32.07 & 37.53 & 13.2958 .4324 .7926 .70 & \\
13.00 & 31.21 & 37.48 & 14.8062 .3129 .6129 .88 & \\
14.00 & 30.42 & 37.39 & 16.1065 .9834 .3432 .91 & \\
& & & & & \\
\hline
\end{tabular}

Source: Bloomberg, and author's calculation.

* Compared with the pre-restructuring cash flow and exchanged into cash, 2012 Bonds and 2030 Bonds at a given discount rate. 


\section{Distribution Provisions}

The principle of intercreditor equity in distribution represents one the main objectives of bankruptcy legislation. However, the absence of an international bankruptcy regime for sovereign debt significantly complicates an orderly debt restructuring process between different and contractually unrelated creditor groups. ${ }^{17}$ The data above show that violations of intercreditor equity can be significant. This suggests that principles underlying debt restructuring proceedings are not observed or, where regulations exist, are too broad to guide restructuring proceedings effectively.

The notion of intercreditor equity rests on existing provisions stipulated in national bankruptcy legislation, debt contracts, and guidelines issued by creditor committees. The first remains limited to corporate debt restructurings. The second establishes equity provisions through event risk covenants that determine ex-ante contractual obligations among creditors and vis-à-vis the debtor. The last outlines principles to be adhered to in the process of restructuring by their consenting members.

Bankruptcy legislation establishes obligations for the treatment of creditors enforceable in court. In corporate bankruptcy, intercreditor equity generally rests on the classification of claims and preference avoidance. Bankruptcy legislation normally requires creditors within each class to be treated equally but allows differently ranked creditors to be treated differently (absolute priority). ${ }^{18}$ Preference avoidance laws recapture transfers made during or near the debtor's threatened or actual bankruptcy proceedings to preserve the debtor's estate for distribution. ${ }^{19}$ The main principles of distribution in bankruptcy are relatively similar in U.S., U.K. and European laws.

\footnotetext{
${ }^{17}$ The IMF Sovereign Debt Restructuring Mechanism (SDRM) proposal launched in 2001 attempted to establish international legislation for the treatment of distressed sovereign debt. The SDRM addresses intercreditor equity with regard to the classification of claims (IMF, 2002). The SDRM proposal acknowledges that different loan terms may require different treatment but concludes that for distribution purposes all non-privileged non-official claims should be placed into one class. The SDRM recommends that all creditors within the same class would receive the same restructuring terms. Official bilateral creditors if they were to be covered under the SDRM would constitute a separate class as it should be possible for official creditors to receive different terms than private creditors as long as private creditors consent. The SRDM has not made specific provision for preference avoidance. Considerations to implement the SDRM have been postponed indefinitely by the International Monetary and Financial Committee at the IMF/World Bank spring meetings of April 2003.

${ }^{18}$ The seniority of claims determines the distribution. Under U.S. law, each creditor class is compensated only after classes designated as senior are paid in full (11 USC 1129 (b) (2) (B) (ii)). Under English law, absolute priority is granted for debts that are not of preferential rank (Technical Manuel Chapter 36).

${ }^{19}$ The prohibition of inequitable transfers has its origin in 16th century English law. The focus of English law was not to ensure a mathematical pro-rata distribution of assets but rather to prevent a debtor from administering a distribution based on own and unchecked criteria. The principle of preference followed in the 18th century by advancing a central element of modern preference legislation by distinguishing between transfers as part of the ordinary course of business and transfers detrimental to other creditors. However, only in 1869, a preference provision was drafted into English bankruptcy legislation providing that any payment made within three months of bankruptcy, for the purpose of giving the creditor a preference, was void.
} 
U.S. bankruptcy legislation establishes the principles that govern equitable distribution and preference avoidance with the reorganization plan under Chapter 11 of the U.S. bankruptcy code (11 USC). Provisions for intercreditor equity are based on implicit and explicit distribution and valuation principles and guided by the classification of claims. ${ }^{20}$

The distribution of claims under the U.S. code is subject to a pro rata distribution for claimants of the same class (11 USC, 726 (b)). Confirmation of a reorganization plan by the court also considers if each holder of a claim of a class receives an equal amount of any payment made under the plan (11 USC, 1129 (b)(2)). English law stipulates that all equally ranked creditors receive equal proportions if assets are insufficient to pay debt in full (Technical Manuel Chapter 36 36.68). Enforcement provisions under English law for loans issued under a trust deed typically refer to any proceeds obtained by the trustee to be distributed pro rata to creditors.

U.S. bankruptcy legislation rests on the principles of going concern and fair valuation in present value terms. The U.S. bankruptcy code establishes that the valuation of debt should be based on the assumption that the entity is a going concern. A market valuation that reflects the prevailing distress of the debtor may therefore unduly depress the valuation of a debt

American bankruptcy law introduced preference provisions in the bankruptcy act of 1841 . The act defined and prohibited preferences making any transfer illegal if made for the purpose of benefiting a particular creditor. The bankruptcy act of 1898 promulgated an elaborate scheme to ensure ratable distribution. The bankruptcy reform act of 1978 created a specific and technical rule for the definition for preference: Section 547 states that a preference consists of a transfer of the debtor's property: 1) to or for the benefit of a creditor; 2) for or on account of an antecedent debt owned by the debtor prior to such transfer; 3 ) made while the debtor was insolvent; 4) made on or within 90 days before the date of the filing of the petition; 5) that enables such creditor to receive more than such creditor would receive if the case were a case under Chapter 7 (liquidation). The debtor's estate representative has the burden of proving that none of the above provisions are violated to prevent transfers of being voided.

The U.S. bankruptcy code makes specific provisions to allow recovery of a preference against unsecured creditors (section 550). However, the law sets forward defenses a creditor might assert including: 1) a transfer is protected to the extent that the transfer was a contemporaneous exchange for new value (contemporaneous exchange); 2) a transfer is insulated from preference litigation if payments were made in the ordinary course of business (ordinary course transfers); and 3) transfers are exempted to the extent that the creditor gave new value for the benefit of the debtor (enabling loans).

${ }^{20}$ The reorganization plan may place a claim in a particular class "if such claim is substantially similar to the other claims of such class" (11 USC, 1122). The absence of language defining "substantially similar" claims makes classification subject to a wide range of interpretation and arbitrariness. While 11 USC., 1122 bars aggregating dissimilar claims in the same class, it does not explicitly address whether similar claims must be placed in the same class. Case law indicates that "this issue of the permissibility of separate classification of similar types of claims is one that has yet to be addressed, and it remains a "hot topic" both among practitioners and in the academic community" (Aetna v. Chateaugay Corporation, 2nd Cir., 1995). The court may force creditors to accept the plan (cram down) if the plan does not "discriminate unfairly, and is fair and equitable, with respect to each class" (11 USC, 1129 (b)). The U.S. Congress addresses the issue of inter-class equality by demanding that "a class is not to be unfairly discriminated against with respect to equal classes. There is no unfair discrimination as long as the total consideration given all other classes of equal rank does not exceed the amount that would result from an exact aliquot distribution" (U.S. House report 95-595). The guidance provided by case law and the legislative history of the code suggests that equally ranked creditors in different classes should be treated as if they were grouped in one class. 
which would be inconsistent with the notion of going concern and is as such irrelevant for insolvency valuation (11 USC, 101, 32, A) ${ }^{21}$ Confirmation of a plan rests on the premise that each holder of a claim will receive the present value equal to the allowed amount of the claim (11 USC 1129 (b) (2)). The U.S. Congress asserts that a claim "is to be valued as of the effective date of the plan, thus recognizing the time-value of money" (U.S. House report 95-595). The court also establishes that all claims by class must be subject to the same discount rate to preserve equality of treatment of claims (CF\&I Fabricators of Utah $v$. Pension Benefit Guaranty Corporation, 10 ${ }^{\text {th }}$ Cir., 1998). ${ }^{22}$

Commercial debt contracts establish contractual relations among creditors party to the contract and vis-à-vis other creditors. Equity and preference provisions in standard loan and bond documentation under English and New York laws are based on equity covenants in the underlying commercial contracts. ${ }^{23} 24$ The covenants normally do not contain specific distribution provisions but establish the relationship between creditors of a given debt issue and between creditors of different issues. The former rests mostly on the notion of pari passu and the latter on negative pledge, cross-default, and acceleration covenants. ${ }^{25}$ Commercial debt contracts make usually no specific provisions about the valuation of the underlying claim but business practices show that valuations are performed in present value terms.

The pari passu covenant represents a fundamental principle in loan contracts to ensure equity between present and future creditors. Pari passu establishes that creditors are equal among themselves, that is, on an equal footing, and that all payment obligations under the loan agreement, currently and in the future, will rank at least equally with all of other unsecured and unsubordinated obligations. ${ }^{26}$ In the sovereign context, the prevailing interpretation of

\footnotetext{
${ }^{21}$ Under U.S. bankruptcy legislation, while accepting the valuation in present value terms, the courts have often been satisfied if the distribution of claims occurs in terms of face value and not if the market value of the new claims is consistent with the terms of the reorganization.

${ }^{22}$ The U.S. Congress also allows for the notion of risk premium to be introduced in the valuation of claims: "Normally, the interest rate used in the plan will be prima facie evidence of the discount rate because the interest rate will reflect an arms length determination of the risk of the security involved [...]"(U.S. House report 95-595).

${ }^{23}$ Standard loan documentation often contains other equality provisions, such as, mandatory payment, turnover, and sharing clauses.

${ }^{24}$ Under English law, debt is often issued under trust deeds that may include explicit collective action clauses but typically do not address inter-creditor group distribution issues in detail.

${ }^{25}$ Negative pledge obliges the borrower not to grant security in favor of a subsequent creditor unless obligations under a prevailing loan agreement are equally secured. Cross-default specifies certain events under which a default in respect of any payment obligation by the borrower under any loan agreement other than the loan agreement in question constitutes a default. Acceleration provides in the event of default for the full immediate payment of all outstanding principal normally upon meeting certain specified triggers.

${ }^{26}$ For example the pari passu clause in the Offer to Exchange trade indebtedness of the former Soviet Union (FTO) reads: "2030 Bonds constitute direct, unconditional, unsecured and subordinated obligations of the Russian Federation and rank pari passu without any preference among themselves and at least pari passu in all respects with all other present and future unsecured and unsubordinated obligations of the Russian Federation" (Offering Circular, Russian Federation, Offer to Exchange 2030 Bonds and 2010 Bonds for FTOs, November 2002).
} 
pari passu has also been that the clause should prevent sovereign borrowers from passing legislation that would increase the risk of subordination of certain creditors. ${ }^{27}$ However, the meaning of pari passu in the sovereign debt context has recently been subject to substantial controversy and there does not seem to be a consensus about its definition (Buchheit, 1991; Scott and Jackson, 2002). ${ }^{28} 29$

Creditor committees represent important coordination and enforcement mechanisms among creditors that may or may not be in contractual relations to each other. Commercial and official debt are treated in different committees that provide guidelines for their consenting members. Such guidelines may be supported by existing contractual relations among creditors or provide for implicit and explicit obligations of the debtor for the treatment of its creditors.

The restructuring of commercial debt often occurs under the auspices of the London Club or bondholder associations. Official bilateral loans are normally restructured under the guidelines of the Paris Club of official bilateral creditors. Official multilateral debt is treated exclusively under the framework of the HIPC Initiative of the IMF and World Bank:

- Paris Club: $:^{30}$ Paris Club negotiations are based on consensus among its members and guided by a "comparability of treatment" principle that stipulates that a debtor is to seek a treatment by other creditors similar to that provided by the Paris Club. Comparability of treatment implies that the debtor country commits itself to seek from nonmultilateral creditors, notably other official bilateral creditor countries that are not members of the Paris Club, and private creditors a rescheduling on

\footnotetext{
${ }^{27}$ The interpretation of pari passu in the U.S. corporate bankruptcy context is that an obligation is similar in seniority than other indebtedness of the borrower with regard to the priority of payments under liquidation (see above).

${ }^{28}$ A Brussels appeals court in September 2000 ruled in favor of Elliott Associates against Banco de la Nación and the Republic of Peru. Elliott sought full payments from Peru on loans which were not submitted, albeit eligible, to Peru's Brady exchange that closed in March 1997. In September 2000, Peru attempted to settle interest payments on its Brady bonds within the course of regular coupon payments. Elliott argued that such payments cannot be made in full if Elliott is not paid in full based on its unrestructured loan terms. Elliott litigated on the assertion that Peru was violating the pari passu clause of the underlying loan documentation by paying one group of creditors and not Elliott (Gulati and Klee, 2001; Scott and Jackson, 2002). Elliott argued that pari passu means that all payments must be made on a pro rata basis preventing preferential payments to certain creditors. The Brussels decisions seems to represent the first formal recognition in the sovereign debt context that the pari passu clause gives creditors the right to be paid pro rata with the rest of creditors covered by the clause (Scott and Jackson, 2002).

${ }^{29}$ The Argentine government filed on December 19, 2003 (exactly on the anniversary of the outbreak of the 1994 Mexican crisis) a request with the U.S. Southern District Court of New York to clarify the principle of pari passu in Argentine loan contracts.

${ }^{30}$ The Paris Club, established in 1956, represents a group of major bilateral official creditors to seek coordinated debt restructuring of official claims on distressed sovereign borrowers. There are currently 19 permanent members of the Paris Club: Austria, Australia, Belgium, Canada, Denmark, Finland, France, Germany, Ireland, Italy, Japan, Netherlands, Norway, Russian Federation, Spain, Sweden, Switzerland, United Kingdom, United States.
} 
comparable terms to those negotiated with the Paris Club. ${ }^{31}$ The Paris Club specifies as a general rule, that comparability of treatment is assessed with the effect of private treatments compared to the effect of Paris Club treatments in terms of duration, present value and flow relief. ${ }^{32}$ The Paris Club as a rule uses as a discount rate commercial interest reference rates (CIRR) that represent commercial interest rates in the domestic market of the currency concerned of prime borrowers. ${ }^{33}$

- Heavily Indebted Poor Countries Initiative (HIPC): HIPC represents the most comprehensive sovereign debt relief effort to date and establishes a framework within which debt relief is phased in with the participation of multilateral, bilateral, and commercial creditors. The framework requires all creditors to provide equal concessions under the principle of comparability of treatment as stipulated by the Paris Club (Appendix B).

- London Club: ${ }^{34}$ The London Club rests on the premise that all similarly situated commercial creditors must be treated equally, both in terms of the rescheduling of their existing exposure and their participation in any new credit facilities. The restructuring provisions require that all participants to a rescheduling agreement must be unanimous in respect of any amendment or waiver and especially as regards loan commitment of all creditors, interest payable, amortization dates, and amounts of repayment (unanimity rule). Equal treatment is ensured through the contractual provisions in restructuring and new money agreements in line with covenants in standard loan agreements.

- Emerging Markets Traders Association (EMTA) and Emerging Markets Creditors Association (EMCA): ${ }^{35}$ EMTA and EMCA have not established explicit guidelines on

\footnotetext{
${ }^{31}$ The Paris Club restructuring terms are guided by the financing needs and the income level of the debtor (Table 4). The Paris Club will only consider payment relief if the debtor is under an IMF-supported program and will provide debt relief consistent with an IMF adjustment program. The Paris Club is guided exclusively by restructuring provisions implicit in the IMF-supported adjustment program. Calls for "two-way comparability", in which concessions granted by the private sector should be matched by the Paris Club (see EMTA, "Burden-Sharing in 2001: Now it's time to reform the Paris Club," February 13, 2001, www.emta.org/emarkets/burden5.pdf), are therefore rejected by the Paris Club. The Paris Club in October 2003 agreed to allow greater flexibility in the restructuring debt of non-HIPC countries (Evian approach).

32 www.clubdeparis.org.

${ }^{33}$ CIRRs are published by the OECD (www.oced.org).

${ }^{34}$ The London Club has traditionally represented an ad-hoc grouping of commercial banks to lead negotiations to restructure claims on distressed sovereign borrowers. Banks with the greatest exposure to a proposed restructuring form a committee to protect the interests of all banks which have loan agreements with the debtor country (bank advisory committee).

35 The increasing importance of bondholders in sovereign borrowing has led to the proliferation of bondholder associations. EMTA, established in 1990, represents the emerging markets trading and investment community and seeks to promote the development of efficient and transparent market conditions for emerging markets instruments and provides a forum that enables market participants to identify issues of importance to the trading and investment community, and develop consensus approaches to addressing industry problems and opportunities. EMCA, established in 2000, aims at representing bondholders of emerging markets debt to provide orderly debt restructuring conditions.
} 
distribution but have implicitly expressed the view that equity of official and private creditors should guide sovereign debt restructuring. ${ }^{36}$ Commercial creditor committees have not issued specific guidelines on the valuation of claims but prevailing market practice suggests that claims are to be valued at market terms, that is, present value terms.

The different provisions for intercreditor equity in debt restructuring indicate common principles in distribution. These rest on the notion that distribution should be equitable based on pro rata distribution and pari passu. The former determines whether distribution is perceived as equitable across different creditor groups to ensure horizontal equity. The latter prevents subordination of creditors to maintain vertical equity net of absolute priority.

The valuation principles explicit and implicit under different restructuring provisions establish only broad guidelines to assess actual distribution. ${ }^{37}$ This implies that while there is acceptance that creditors should receive an equitable share in distribution, assessment of whether equal distribution has been achieved remains near impossible across different creditor groups.

\section{A Proposal}

The current debate about sovereign debt restructuring suggests the need for commonly agreed and transparent distribution rules. As such, established ex-ante guidelines would serve as important ex-post creditor coordination mechanism, reduce possible aggregation problems, and enhance the predictability of restructuring outcomes. These guidelines could constitute part of a code of conduct for consenting creditors in sovereign debt restructuring proceedings. The fact that most restructuring parameters are easily quantifiable allows to establish an unambiguous measure of whether equitable distribution has been achieved.

The notion of intercreditor equity in distribution is considered here to rest on pro-rata distribution based on specific valuation criteria. As such, pro-rata distribution refers to distribution with regard to different prevailing approaches to debt restructuring, that is, debt and cash-flow reduction and average life extension. While pro-rata distribution may not necessarily reflect preferences of individual creditors, it seems the most accepted approach to equitable distribution. The distribution rules are based on fundamental principles derived from existing provisions in loan contracts, bankruptcy legislation, and guidelines issued by creditor committees:

\footnotetext{
${ }^{36}$ Representative private sector associations argued that "inequity in the treatment of private and official bilateral claims allows bilateral creditors to continue to operate in a system that at times afforded them more favorable terms" (EMTA, "Sovereign Debt Restructuring," December 6, 2002, www.emta.org/ndevelop/SDRM.pdf).

${ }^{37}$ Scott and Jackson (2002) argue, with regard to the outcome of the Elliott Associates ruling (footnote 28), that lack of clarity in key bond contract covenants also suggest that boilerplate provisions that open up the possibility of having another decision contrary to the interest of main creditors should be avoided.
} 
- Eligible debt: The inclusion of debt for restructuring should be as broad as possible to maximize participation and ensure intercreditor equity. However, creditor groups maintain different instruments some of which may not be eligible or not desirable for restructuring. To ensure that concessions are equitable across creditor groups, total claims by creditor group should be included in the assessment of equitable distribution whether treated or not. ${ }^{38}$

- Pro rata distribution: Each creditor and creditor group should be subject to a proportional distribution based on the percentage difference between claims prior and after restructuring in present value terms with regard to debt and cash-flow reduction and average life extension. Intercreditor equity is assured if the percent reduction/increase in these parameters is the same across all creditor groups.

- Present value and discount rate: Pre- and post-restructuring obligations should be valued at the same discount rate between similarly ranked creditors to establish a comparable basis of valuation. The valuation of debt should be based on the assumption that the debtor is a going concern to ensure that the discount rate employed is not substantially different from the discount rate that would have been used prior to the start of a debt restructuring. This implies that the chosen discount rate would normally be substantially lower than that implied by prevailing secondary market prices of claims prior to restructuring.

- Debt reduction: Reductions in debt should be valued in present value terms and announced as a floor. The present value concept is also used to determine concession targets within the HIPC Initiative, and as such for official creditors, and is consistent with commercial practice and accounting principles (Appendix C).

- Cash-flow reduction: Cash-flow relief to be extended may best be determined as a floor and will usually coincide with the balance of payments gap over a given period. ${ }^{39}$ The debt service to different creditor groups would have to be reduced proportionally to the cash-flow receipts over the pre-determined period valued in present value terms.

- Average life extension: The extension of maturities may usefully be set as a floor and should ensure an adequate maturity profile avoiding disproportionately high refinancing requirements in any given period. The resulting cash flows should be valued in present value terms.

The determination of an appropriate discount rate is essential to establish a reference for the valuation of claims in debt relief, cash flow, and average life extension. The rate would be subject to an agreement between different creditor groups taking into account similar credits

\footnotetext{
${ }^{38}$ This seems to correspond in spirit to the new Evian approach of the Paris Club that seeks to alleviate previous restrictions on restructuring official bilateral debt.

${ }^{39}$ See footnote 42 .
} 
or prior debt issues. ${ }^{40}$ The discount rate could usefully be determined by the weighted average of claims by each creditor group using their respective representative rates. The appropriate rate is therefore likely to fall between the CIRR rates employed by the Paris Club and market rates used by commercial creditors. ${ }^{41}$

The use of a common discount rate may not properly address the term structure of original claims as longer dated claims may be disproportionately affected by a given rate (Appendix D). The impracticality of deriving an appropriate term structure seems to support the application of a common rate. The existence of acceleration covenants in regular debt contracts, providing that all claims are effectively similar in default upon certain specified triggers, may further justify the use of a common discount rate at least in post-default restructurings.

The combination of present value, cash flow, and average life criteria allow to address comprehensibly the parameters that determine distribution in restructuring and respond to specific payment constraints of a debtor. ${ }^{42}$ Short-term liquidity problems could be addressed by focusing almost exclusively on cash-flow and average life. In this context, the issuance of new money should be treated equivalent to cashflow relief. Solvency problems are likely to rely mostly on debt reduction to restore sustainable levels of indebtedness on the basis of the debtor's long-term payment capacity.

The assessment of distribution in restructuring requires full disclosure of actual debt stocks and flows outstanding to allow an unambiguous verification of changes in the exposure of different creditor groups. Such data could usefully be made available on a centralized website upon presenting a request for restructuring.

\footnotetext{
${ }^{40}$ The chosen discount rate is not aimed at substituting market discount rates and merely acts as an appropriate reference within the equality valuation rules.

${ }^{41}$ The face value of a claim received in distribution would be as good an indicator to determine equitable distribution as the market value of the claims (problem of common denominator). Yet, the level of the discount rate is material when different creditor groups use different discount rates to value their respective shares in distribution and therefore to determine whether equitable distribution has been achieved.

${ }^{42}$ The restructuring of sovereign debt of a debtor in or near default is most often guided by provisions established under an IMF-supported adjustment program and rests on the balance of payments needs established by the IMF to determine the debt relief needed to restore the debtor's solvency or liquidity. The IMF balance of payments analysis specifies the financing gap that needs to be closed and effectively constitutes the "reorganization plan" in sovereign debt restructuring. The IMF requires the debtor country to implement an adjustment program and obtain sufficient financing through new money, debt relief, or other forms of payment to establish the viability of the economic program supported by the Fund. IMF adjustment programs may include exceptional financing from the Paris Club and other creditors in cases where program-financing needs are large and the debtor's payment obligations to such creditors are substantial. As such, the IMF-supported reorganization plan may determine the concession floor in sovereign debt restructuring and effectively represents a cram down provision on all creditors albeit without the legal implications normally associated with such provisions.
} 


\section{CONCLUSions}

The paper shows existence of violation of intercreditor equity in distribution in sovereign debt restructuring and discusses its findings against distribution provisions in debt restructuring proceedings. The paper reviews actual outcomes of recent key restructuring agreements and calculates deviations from equitable distribution. The restructuring outcomes indicate that distribution can differ significantly not only between but also among creditor groups. The latter suggests that while commercial creditors have repeatedly complained of unfair treatment vis-à-vis official creditors, intra-commercial creditor equity has also not been observed. However, data limitations imply that the empirical results obtained are approximations only of actual concessions extended by individual creditor groups.

The paper discusses fundamental elements of distribution in U.S. corporate bankruptcy legislation, loan contracts, and guidelines issued by creditor committees. While distribution provisions in sovereign debt restructuring frameworks and bond contracts exist, and there seems to be broad-based recognition that distribution in debt restructuring should be equitable, they remain too vague to guide effectively restructuring processes. Different creditor groups, in particular official and private creditors, do not share common rules to value concessions in debt restructuring. As such sovereign debt restructuring does not rely on a common basis for comparing individual creditor action. This despite the fact that most restructuring parameters are easily quantifiable and allow to establish an unambiguous measure to determine equitable distribution. The absence of commonly accepted valuation rules imply that the assessment of whether equitable distribution has been achieved will remain elusive.

The paper proposes a set of simple guidelines that may constitute a code of conduct for consenting creditors in sovereign debt restructuring proceedings and allow to enhance the transparency of distribution and valuation for sovereign debtors in or near default and as such strengthen intra -and intercreditor group collective action: i) Distribution should be pro-rata for debt and cash-flow reduction and average life extension valued at a common discount rate for pre- and post-restructured claims, and ii) all parameters to establish debt relief should be pre-announced as determined by the balance of payments need of the debtor. Such guidelines should be accompanied by full disclosure requirements on debt outstanding to allow a verifiable assessment of distribution.

The paper leaves several questions on intercreditor equity open; among others, in light of the relative simplicity of rules that can be established, why have such rules not been defined; what should be an appropriate mechanism of monitoring and enforcing such rules? Subsequent work might usefully address these areas in particular to analyze prevailing incentives that give rise to or have preserved current restructuring processes. The importance of determining an appropriate discount rate also requires further research into identifying optimal search processes for a commonly agreeable rate. 


\section{A. Restructuring Parameters}

\section{Table 4. Paris Club Restructuring Terms}

\begin{tabular}{|c|c|c|c|c|c|c|}
\hline $\begin{array}{l}\text { Non-ODA } \\
\text { terms } \dagger\end{array}$ & $\begin{array}{l}\text { Date of } \\
\text { implementation }\end{array}$ & $\begin{array}{l}\text { Grace } \\
\text { period } \\
\text { (years) }\end{array}$ & $\begin{array}{l}\text { Maturity } \\
\text { (years) }\end{array}$ & $\begin{array}{l}\text { Repayment } \\
\text { schedule }^{2 /}\end{array}$ & $\begin{array}{l}\text { Interest } \\
\text { rate }^{3}\end{array}$ & $\begin{array}{l}\text { Present value } \\
\text { reduction } \\
\text { (percent) }\end{array}$ \\
\hline Ad hoc ${ }^{1 /}$ & $\cdots \cdots$ & & $\cdots$ & $\cdots$ & $\cdots$ & $\cdots$ \\
\hline Classic C & ontinuous & $5-6$ & 9 & Flat/graduated & M & 0 \\
\hline Houston & since Sep. 1990 & Up to 10 & 20 & Flat/graduated & M & 0 \\
\hline \multicolumn{7}{|l|}{ Low-income } \\
\hline Toronto & Oct. 1988-Jun. 91 & up to $8^{5 /} 14$ & ${ }^{5 /} \mathrm{Fla}$ & $\mathrm{t}$ & $\mathrm{M}$ & up to $33.5^{5 /}$ \\
\hline London & Dec. 1991-Dec. 94 & up to $6^{5 / 2} 23$ & ${ }^{5 /} \mathrm{G}$ & raduated & $\mathrm{M} / \mathrm{R}$ & $50^{5 /}$ \\
\hline Naples & since Jan. 1995 & Up to 6 & 23 & Graduated & $\mathrm{M} / \mathrm{R}$ & 67 \\
\hline Lyon ${ }^{6 /}$ & since Dec. 1996 & $\mathrm{Up}$ to 6 & 23 & Graduated & $\mathrm{M} / \mathrm{R}$ & 80 \\
\hline Cologne ${ }^{6 /}$ & since Nov. 1999 & Up to 6 & 23 & Graduated & $\mathrm{M} / \mathrm{R}$ & 90 or more $^{7 /}$ \\
\hline
\end{tabular}

Source: IMF; Paris Club.

$\uparrow$ Non-official development assistance loans that are subject to four restructuring options (debt reduction (DR), debt service reduction (DSR), moratorium interest capitalization reduction (CMI), commercial option). CMI and commercial option are seldomly used under Naples terms. Only DR is used under Lyon and Cologne terms.

1/ Ad hoc terms are normally on a non-concessional basis and constitute once-and-for-all non-replicable restructuring terms. $2 /$ Graduated repayments imply repayments increasing through time.

3/ M=Market rates; $\mathrm{R}=$ Reduced rates. Lower income countries may trade off longer maturities for higher interest rates. 4/ Face value of pre-restructured and post-restructured debt is discounted at commercial interest reference rates (OECD) to establish debt reduction rate. Part of debt reduction option (see 1/) with outstanding debt being rescheduled.

5/ Debt reduction option provides for cancellation of debt with outstanding amounts being rescheduled. A commercial option provided for no reduction by an extension of the grace period and repayment period (up to 14-year grace and 25-year repayment period).

6/ Within the Heavily Indebted Poor Country (HIPC) Initiative by the IMF and World Bank.

7/ Debt reduction sufficient to allow country to reach appropriate debt ratios ( $150 \%$ debt to exports; $250 \%$ debt to fiscal revenues). 
Table 5. Restructuring Terms

Eligible Voluntary restructurings normally specify certain Debt debt that is eligible for an exchange. Post-default restructurings generally comprise all maturities. Separate arrangements are normally made for bank loans and bonded debt. Debt exchanges normally exclude trade creditors but may provide similar arrangements in a separate agreement (Russia, FTO debt). Secured trade credits are normally restructured under the aegis of the Paris Club.

Coverage Restructurings normally cover the outstanding stock of liabilities.

Terms

Voluntary exchanges will generally preserve the present value of the old securities but may achieve certain advantages for the debtor such as releasing cash from collateralized securities (Brady bond exchanges), reducing the nominal value of debt outstanding. Involuntary exchanges provide normally for a reduction in present value due to a combination of extending maturities, a nominal debt reduction, and alteration in interest payments. Concessions are guided by the balance of payments needs of the debtor country.

Late Interest accrued on principal and interest arrears is interest normally restructured. Exchanges may provide for partial cash payments for late interest. Late interest is generally computed at simple Libor plus a fixed spread and provisions for late interest charges and penalties are normally not exercised.
Debt service eligible for rescheduling generally comprises all arrears and maturities falling due during the consolidation period on medium- and long-term debt contracted prior to the first Paris Club restructuring (cutoff date). Pre-cutoff debt normally covers debt not previously rescheduled (NPRD) and debt previously restructured (PRD). For PRD, preference is given to treat obligations under older rather than under more recent agreements. Loans extended after the cutoff date are normally not eligible for restructuring. In exceptional cases where financing gaps cannot be filled by treatment of eligible debt, arrears and nonconcessional portions of post-cutoff debt can be deferred.

Debt service eligible is consolidated into a new schedule for the period of an IMF-supported program (consolidation period). The standard consolidation period is one year but creditor countries have accepted to reschedule the debt falling over two or three years (flow treatment). Some Paris Club treatments apply to the entire stock of debt from which those payments fall due to provide a permanent and final treatment (stock treatment). Stock treatments are provided in the context of the HIPC Initiative and on a case-bycase basis, for countries having established a satisfactory track record with both the Paris Club and the IMF. Debt with an original maturity of up to one year is normally excluded from restructuring.

Restructurings terms are guided by the income level of the debtor country and financing need. Middle-income restructuring terms normally entail only a lengthening of maturities. In October 2003 Paris Club creditors agreed to allow greater flexibility for non-HIPC countries (Evian approach). For lower-income countries, a concessional restructuring normally comprises a reduction in nominal claims. The reduction is based on present value reductions using commercial interest reference rates (CIRR). The Paris Club distinguishes restructuring terms for nonconcessional (non ODA) and concessional (ODA) loans.

Interest accrued on principal and interest arrears. Late interest may be rescheduled depending on the financing need and debt payment record. Interest accrued on rescheduled debt (moratorium interest) is only rescheduled in exceptional circumstances. 


\section{B. Distribution under HIPC}

The Heavily Indebted Poor Countries (HIPC) Initiative represents the most comprehensive framework for sovereign debt restructuring to date launched by the IMF and World Bank in 1996. The HIPC Initiative provides explicit guidelines for restructuring by creditor group. The decision point documents of HIPC eligible countries specify the amount of debt relief that is scheduled to be implemented upon reaching a certain stage under the initiative. ${ }^{43}$

The brief review here of distribution under HIPC refers to countries with significant commercial debt outstanding. The scheduled restructuring outcomes seem overall not to reveal a systematic treatment. However, the differences between the Paris Club restructurings rests largely on the restructuring criteria used by the Paris Club. The exclusion of post-cutoff debt in some cases, application of flow and stock treatments, and significant differences in the cutoff date further complicate the comparison between different restructuring terms (see Appendix A).

The data show the treatment by country and creditor group before a common present value reduction factor is applied uniformly to all creditor groups (Table 6). The Cameroon restructuring postulates a present value reduction of 30 percent for Paris Club creditors and of 67 percent for commercial creditors. The Tanzania restructuring provides for an increase in present value for Paris Club creditors and a decline of 45 percent for commercial creditors.

\footnotetext{
${ }^{43}$ In a first phase traditional debt relief is provided from bilateral official creditors in the Paris Club providing a reduction of claims based on traditional debt relief (of up to 67 percent (Naples terms)). In a second phase (decision point), upon meeting certain debt ratios after traditional relief, creditors grant an additional reduction of claims of up to 90 percent (Cologne terms) in cumulative terms.
} 
Table 6. Debt Relief under HIPC

\begin{tabular}{|c|c|c|c|c|}
\hline & $\begin{array}{r}\text { Nominal } \\
\text { claims } \\
\text { (US\$ mill } \\
\text { ion) }\end{array}$ & $\begin{array}{r}\text { Pre- } \\
\text { acturing } \\
\text { present } \\
\text { value } \\
\$ \text { millio } \\
\mathrm{n})\end{array}$ & $\begin{array}{r}\text { Post- } \\
\text { restructuring } \\
\text { present } \\
\text { value } \\
\text { (US\$ millio } \\
\mathrm{n})^{*}\end{array}$ & $\begin{array}{r}\text { Present } \\
\text { value } \\
\text { reduction } \\
\text { (percent) }\end{array}$ \\
\hline Cameroon Jun-1999 & $7,8026,6$ & 014,6 & 90 & -29.0 \\
\hline Multilateral creditors & $1,6421,2$ & 061,2 & 06 & 0.0 \\
\hline Paris Club & $5,3654,6$ & 143,2 & 05 & -30.5 \\
\hline Pre-cutoff & $4,0883,5$ & 202,1 & 11 & -40.0 \\
\hline Post-cutoff & $1,2761,0$ & 941,0 & 94 & 0.0 \\
\hline Non Paris Club & 998549 & & & -42.4 \\
\hline Commercial creditors ${ }^{2 /}$ & 696696230 & & & -67.0 \\
\hline Mozambique Dec-2000 3/ & $5,1253,3$ & 511,2 & 08 & -63.9 \\
\hline Multilateral creditors & 1,348571546 & & & -4.3 \\
\hline Paris Club & 2,755 & 2,076 & 535 & -74.2 \\
\hline Pre-cutoff 2,4 & 79 & 1,895 & 380 & -79.9 \\
\hline Post-cutoff & 276181155 & & & -14.6 \\
\hline Non Paris Club & 876 & 560 & 92 & -83.6 \\
\hline Commercial creditors ${ }^{4} 147$ & & 145 & 36 & -75.3 \\
\hline Nicaragua Dec-1999 1/ & $6,4125,5$ & 404,5 & 23 & -18.4 \\
\hline Multilateral creditors & $2,1541,5$ & 541,5 & 54 & 0.0 \\
\hline Paris Club & $1,6251,4$ & 111,2 & 05 & -14.6 \\
\hline Pre-cutoff & $\ldots \ldots \ldots$ & & & $\ldots$ \\
\hline Post-cutoff & $\ldots \ldots \ldots$ & & & $\ldots$ \\
\hline Non Paris Club & $2,3622,3$ & 031,7 & 07 & -25.9 \\
\hline Commercial creditors ${ }^{5 /}$ & 271 & 272 & 57 & -79.0 \\
\hline Tanzania Jun-2001 ${ }^{1 /}$ & $6,1864,1$ & 553,6 & 54 & -12.1 \\
\hline Multilateral creditors & $3,5151,9$ & 011,9 & 01 & 0.0 \\
\hline Paris Club & $1,5471,1$ & 821,3 & 09 & 10.8 \\
\hline Pre-cutoff & $\ldots \ldots \ldots$ & & & $\ldots$ \\
\hline Post-cutoff & $\ldots \ldots \ldots$ & & & \\
\hline Non Paris Club & 926878335 & & & -61.8 \\
\hline Commercial creditors ${ }^{2 /}$ & 198195108 & & & -44.6 \\
\hline
\end{tabular}

Source: IMF decision points documents.

* The post-restructuring value excludes a further reduction to be reached at the decision point. This reduction is based on a common factor for all creditors from the post-restructuring value cited above.

1/ Restructuring amounts after Naples terms at non-official development assistance (ODA) terms.

2/ Commercial debt buy-back programs initiated in 2001 to purchase debt at US\$0.12 to the dollar.

3/ Restructuring amounts after Lyon-terms at non-ODA terms.

4/ Mozambique concluded a commercial debt buy-back program in December 1991 purchasing US\$198 million of nominal debt at US\$0.10 to the dollar.

5/ Nicaragua concluded a commercial debt buy-back program in December 1995 purchasing US $\$ 1,819$ million of nominal debt at US $\$ 0.08$ to the dollar. 


\section{Present Value Accounting Principles}

Corporate and sovereign accounting practices make certain provisions about the valuation of claims. U.S. accounting rules as determined by the Statement on Financial Accounting Standards (SFAS) and Financial Accounting Standards Board (FASB) allow to derive from the principles of accounting for distressed debt the valuation principles underlying the valuation of claims. The IMF Government Finance Statistics (GFS) handbook provides guidelines for the accounting of distressed claims by governments.

U.S. accounting rules stipulate that impaired loans are to be measured based on the present value of expected future cash flows discounted at the loan's effective interest rate or, as a practical expedient, at the loan's observable market price or the fair value of the collateral if the loan is collateral dependent (SFAS 15, FASB statement no. 115). U.S. accounting rules provide that the economic loss at the time of restructuring equals the difference between the carrying amount (amount used for balance sheet purposes) of the loan and the present value of cash payments after restructuring. U.S. accounting rules also specify that the appropriate accounting of a restructured debt incorporates carrying forward only the present value of future receipts, with the lender recognizing a loss equal to the decrease in the present value of the restructured loan (SFAS 15).

The GFS handbook establishes that with regard to debt restructuring loans that have become marketable in secondary markets should be reclassified as securities other than shares and valued at market prices. In addition, general government units may find that other loans are worth less than their nominal value on the evidence of similar debt that has been traded in the market (for example, under loan-for-equity swaps). In such circumstances, a memorandum item should be recorded noting the apparently lower value of the loans.

\section{Present Value and Discount Rate}

The calculation of concessions in debt restructuring depends on the discount rate used to calculate the present value of claims. The discount rate therefore determines the basis of comparison of concessions extended and different discount rates may lead to different conclusions about the concessions extended. The relationship between present value and discount rate is not linear. Longer-dated debt is disproportionately more depressed relative to shorter-dated debt under a high compared with a low discount rate (Figure 1). Different discount rates illustrate that for the same bond valued at 7 percent or at 15 percent, the exchange into a new instrument valued at the same discount rate implies differences in haircuts, that is, the percent change between pre- and post restructuring present value, from 30 percent to 65 percent for a two-year maturity pre-restructured claim (Figure 2).

The relationship between average life and present value implies that at a given discount rate longer-dated debt has a lower present value. Similarly, at a given discount rate, higher cash-flow relief provides for a lower present value. However, the use of step-up coupons and embedded options may compensate for front-loaded relief by providing creditors with higher

back-loaded cash flow, thus restoring the present value of the original claim. The measures of 
cash flow and average life in isolation to determine debt reduction therefore reveal little about actual relief extended over the life of the debt.

Figure 1. Present Value and Discount Rates

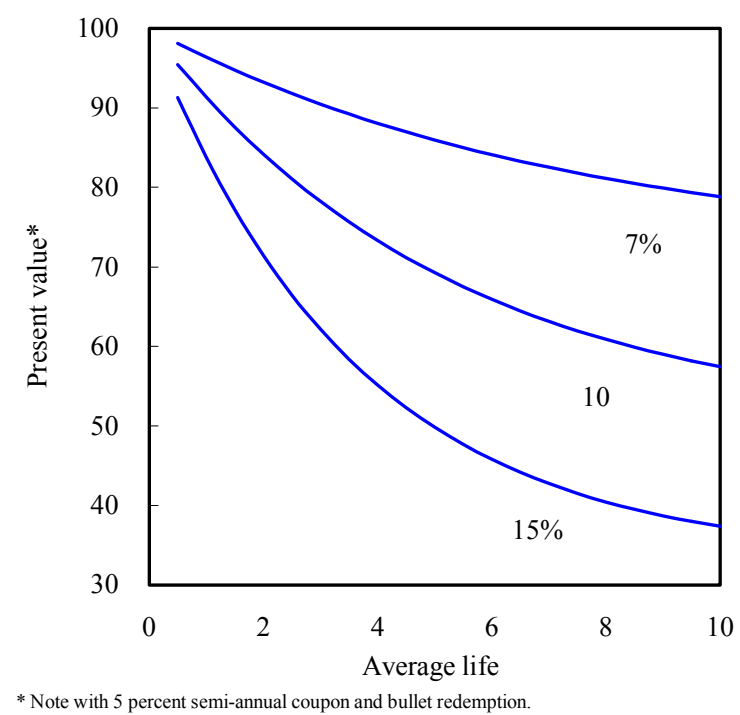

Figure 2. Concessions and Discount Rate

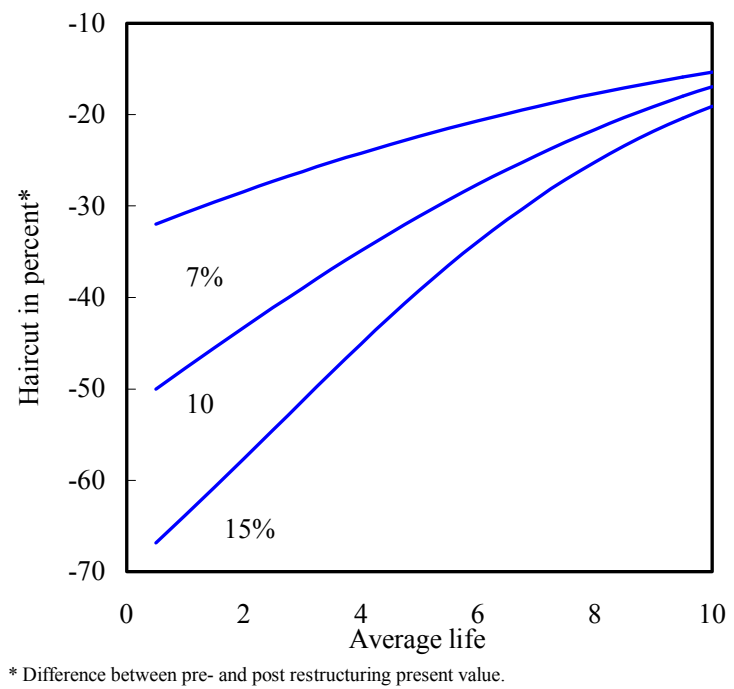




\section{REFERENCES}

Bertola, G. (2000), "Macroeconomics of distribution and growth," in Atkinson, A. and Bourguignon, F. (eds.), Handbook of income distribution, Amsterdam.

Brams, S. and Taylor, A. (1996), Fair division: From cake cutting to dispute resolution, Cambridge.

Buchheit, L. (1991), “The pari passu clause sub specie aeternitatis,” International Financial Law Review, December, 11.

Clark, J. (1998), "Fairness in public good provision: an investigation of preference for equality and proportionality," Canadian Journal of Economics, 708-729.

Couillault, B. and Weber, P. (2003), "Towards a voluntary code of good conduct for sovereign debt restructuring," Financial Stability Review, Bank of England, 154-162.

Cowell, F. (1977), Measuring inequality, New York, NY.

Dixon, L. and Wall, D. (2000), "Collective action problems and collective action clauses," Financial Stability Review, Bank of England, 142-151.

Eichengreen, B. (2003), "Restructuring sovereign debt," Journal of Economic Perspectives, 75-98

Eichengreen, B. and Mody, A. (2003), "Is aggregation a problem for sovereign debt restructuring?" CEPR discussion paper 3771.

Friedman, B. (2000), “Debt restructuring,” NBER Working paper 7722.

Ghosal, S. and Miller, M. (2003), "Co-ordination failure, moral hazard and sovereign bankruptcy procedures," Economic Journal, 276-304

Gulati, M. and Klee, K. (2001), "Sovereign piracy," research paper no. 01-7, UCLA School of Law.

IMF (2001), "Involving the Private Sector in the Resolution of Financial Crises-The Treatment of Claims of the Private Sector and Paris Club Creditors," available via the Internet at www.imf.org/External/NP/psi/2001/eng/062701.pdf.

(2002), "The design of the sovereign debt restructuring mechanism-further consideration," available via the Internet at www.imf.org/external/np/pdr/sdrm/2002/112702.pdf. 
(2003), "Reviewing the Process for Sovereign Debt Restructuring within the Existing Legal Framework," www.imf.org/external/np/pdr/sdrm/2003/080103.pdf, IMF website

Kahneman, D., Knetsch, J., and Thaler, R. (1986), "Fairness as a constraint on profit seeking: Entitlements in the market," American Economic Review, 728-741.

Kaplow, L. (2000), "Horizontal equity: New measures, unclear principles," NBER Working Paper 7649

Krueger, A. (2002), A new approach to sovereign debt restructuring, Washington, IMF.

Pazner, E. and Schmeidler, D. (1978), "Egalitarian equivalent allocations: A new concept of economic equity," Quarterly Journal of Economics, 671-687.

Rabin, M. (1993), "Incorporating fairness into game theory and economics," American Economic Review, 1281-1302.

Rogoff, K. and Zettelmeyer, J. (2002), "Bankruptcy procedures for sovereigns: A history of ideas 1976-2001," IMF Staff Papers, 470-503

Scott, H. and Jackson, H. (2002), "Sovereign debt restructuring: Should we be worried about Elliott," unpublished, Harvard Law School, International Finance Seminar, Cambridge, MA

Thomson, W. and Varian, H. (1985), Theories of justice based on symmetry, in Hurwicz, L., Schmeidler, D. and Sonnenschein, H. (eds.), Social goals and social organization, essays in memory of Elisha Pazner, Cambridge.

Warner, J.B. (1977), "Bankruptcy, absolute priority, and the pricing of risky debt claims," Journal of Financial Economics, 239-276. 